\title{
THE CORRELATION BETWEEN ANTI CARDIOLIPINE \& PROTEIN C \& PROTEIN S AND UMBILICAL \& MIDDLE CEREBRAL ARTERY BLOOD FLOW IN INTRA UTERINE GROWTH RESTRICTED FETUS
}

\author{
By
}

\author{
Aiman Mohamed Atitou Ahmed, Yehia Abd El-Salam Wafa, Fahd Abd \\ El-Aal Mohamed and Salah Ahmed El-Beltagy*
}

Departments of Obstetrics and Gynecology and Clinical Pathology*, Faculty of Medicine, Al-Azhar University

\begin{abstract}
Background: Fetal growth disorders are an important cause of perinatal morbidity and mortality. The accurate assessment of fetal growth during pregnancy is difficult, but recent advances have improved this important aspect of obstetric care with positive implications for antenatal patients and their babies. Intrauterine growth restriction (IUGR) is the pathological counterpart of small-for-gestational age (SGA). So IUGR is a condition with an increased risk of a pathological condition that adversely affects the inherent potential growth of the fetus.
\end{abstract}

Objective: To determine the correlation between anti cardiolipine \& protein $\mathrm{C} \&$ protein $\mathrm{S}$ and umbilical \& middle cerebral artery blood flow in intrauterine growth restriction fetus.

Patients and Methods: This study is prospective observational study, was conducted on 130 pregnant women presented to us at (Al-Azhar university Hospitals) (Al-Hussin),from 1/1/2017 to 1/1/2019, where 100 of them were diagnosed with intra uterine growth restriction fetuses at (28-32 weeks, study group) and recruited from the obstetric outpatient clinic and department and 30 women with normal pregnancy were also recruited as (control group) also at (28-32 weeks) from those who coming for routine antenatal care.

Results: Majority of the patients forming our study were in the age group of 20 to 30 years and most of them were Primigravida. Associated risk factors were Hypertension disorders with pregnancy (PIH\&PET), diabetes mellitus and anemia, PIH was the most common risk factor. Pathologically Growth restricted Fetuses showed abnormal Trends in the Doppler indices elevated indices in umbilical artery and low indices in middle cerebral artery (MCA) and there is a significant correlation with positive thrombophilia (anticardiolipin, \& protein S), but not significant correlation with protein C.

Conclusion: The value and accuracy of the Doppler indices (S/D,RI\&PI) of the umbilical \& middle cerebral arteries and its correlation with some thrombophilia markers (anticardiolipin, protein $\mathrm{C} \&$ protein $\mathrm{S}$ ) in the IUGR, is a better index for predicting adverse outcomes in IUGR when compared with control group.

Keywords: Anti Cardiolipine \& Protein C \& Protein S, Umbilical \& Middle Cerebral Artery Blood Flow, IUGR.

\section{INTRODUCTION}

Intrauterine growth restriction (IUGR), also known as "intrauterine growth retardation" or "fetal growth restriction", is a term applied to a condition of poor growth of the fetus in utero. The condition results in an "infant small for date" or "dysmature infant" that is defined as having a weight at or below the 10th 
percentile for the expected birth weight at a given gestational age (Sadler et al., 2010).

Fetuses at risk for IUGR are susceptible to potential intrauterine environment that leads to fetal hypoxia and fetal acidosis (Zelop et al., 2013).

The main distinction between SGA and FGR is that a SGA fetus may be small but not at increased risk of adverse perinatal outcome, while a fetus with size above the 10th percentile may be FGR and at increased risk of adverse perinatal and long-term outcome (Bligh et al., 2019).

Overall, growth-restricted fetuses have a higher rate of conditions associated with prematurity, experience worse neurodevelopmental outcome and are at increased risk of non-communicable diseases in adulthood, such as hypertension, metabolic syndrome, insulin resistance, Type-2 diabetes mellitus, coronary heart disease and stroke. Prenatal recognition of fetal growth restriction (FGR) is a major factor identified in strategies aimed at preventing stillbirth, in which up to $30 \%$ of cases are associated with FGR or small-for-gestational age (SGA) in the late third trimester (Nohuz et al., 2020).

IUGR is a frequent cause of stillbirth, perinatal morbidity, and long term sequels, but its etiology is unknown in most cases (Cunningham et al., 2010).

Fetal growth is a dynamic process and its assessment requires multiple observations of fetal size over time. Fetal size is determined through biometric evaluation of the head circumference, biparietal diameter, abdominal circumference (AC) and femur length and/or derivation of estimated fetal weight (EFW) computed by different formulae. The ISUOG Guidelines on ultrasound assessment of fetal biometry and growth describe methodology, reference ranges, growth standards and quality-control processes for appropriate assessment of fetal biometry and diagnosis of fetal growth disorders (Salomon et al., 2019).

Fetuses with birth weight below the 10th percentile are at increased risk of stillbirth and perinatal mortality, with those with birth weight below the 3rd percentile being at the highest risk. For this reason, fetal size at the lower extreme of the growth charts, for example AC or EFW below the 3rd percentile for given growth charts, can be used as an isolated criterion to define FGR at any gestational epoch (Gordijn et al., 2016).

Changes in flow velocity waveforms are observed in various fetal vascular beds, and Doppler surveillance is based on the relationship between circulatory changes and the fetal condition (Vasak et al., 2015).

Growth restriction due to placental insufficiency occurs, and there may also be a change in the fetal cerebral waveforms that suggests increased blood flow to the brain (brain-sparing effect). Fetal middle cerebral artery velocimetry has been suggested as a predictor of fetal hypoxemia when a characteristic increase in diastolic blood velocities was present as a sign of fetal brain-sparing (Lausman et al., 2013).

However, abnormal early umbilical artery abnormalities and middle cerebral artery signals do not necessarily predict the outcome in growth restricted fetuses. In addition, examination of middle 


\section{THE CORRELATION BETWEEN ANTI CARDIOLIPINE \& PROTEIN C... 97}

cerebral artery velocimetry in complicated pregnancies has indicated that the brainsparing effect is an early sign of fetal hypoxemia in fetuses who still have adequate reserves to cope with the stress of labor and vaginal delivery and therefore is of limited value for the prediction of the fetal outcome and the optimal time for delivery (Miller et al., 2014).

When the resistance in the umbilical vasculature increases, fetal carotid Doppler wave forms remain within normal range. However, when the fetal condition worsens, the cerebral resistance index values decrease as a result of cerebral vasodilatation. This phenomenon, called the "brain sparing effect", may be a protective process intended to prevent fetal cerebral hypoxia. Later finding include abnormal Doppler pulsatility of the Middle Cerebral Artery (M.C.A.) and reversed flow in umbilical artery (Hoffman et al., 2012).

Successful pregnancy outcome is dependent on the development and maintenance of adequate placental circulation. Abnormalities of placental vasculature may result in a number of gestational pathologies, such as intrauterine growth restriction (IUGR) (Karakantza et al., 2012).

Congenital and acquired thrombophilias are the most common predisposing factors for thromboembolism, but they may also contribute to pathophysiological processes involved in recurrent pregnancy loss, fetal death, IUGR (Kist et al., 2012).

Adverse pregnancy outcome in women with thrombophilia is associated with placental vascular damage and impaired gas exchange and reduced blood oxygen carrying capacity and impaired fetal growth (Lausman et al., 2013).

The aim of this study was to determine the correlation between anti cardiolipine \& protein $\mathrm{C} \&$ protein $\mathrm{S}$ and umbilical \& middle cerebral artery blood flow in intrauterine growth restriction fetus.

\section{PATIENTS AND METHODS}

This study is prospective observational study, was conducted on 130 pregnant women presented to us at (Al-Azhar university Hospitals) (Al-Hussin), from $1 / 1 / 2017$ to $1 / 1 / 2019$, where 100 of them were diagnosed with intra uterine growth restriction fetuses at (28-32 weeks, study group) and recruited from the obstetric outpatient clinic and department and 30 women with normal pregnancy were also recruited as (control group) also at (28-32 weeks) from those who coming for routine antenatal care.

\section{Inclusion criteria:}

- Age of mother between 18-38 years.

- Single intra uterine pregnancy (as proved by clinical examination and ultrasound).

- Gestational age from 28-32 weeks (assessed by the date of the last menstrual period).

- BMI (kilograms per square meter): (less than $30 \mathrm{~kg} / \mathrm{m}^{2}$ ).

\section{Methods:}

Informed consent was taken from all the patients. Detailed history and through examination was done. All relevant investigations were carried out. The relevant data obtained was recorded in the standard prepared proforma. 
1. Full history taking including current or past illness.

2. Full clinical examination including: General examination and abdominal examination.

3. Ultrasound and Doppler studies were carried out to determine composite Ultrasound gestational age, estimated fetal weight, as well as umbilical and middle cerebral Doppler studies (S/D ratio \& RI \& PI indices) and this was repeated every two weeks till delivery Further management of the cases was decided depending on the clinical status of the patients and the Doppler report, and pregnancies were terminated whenever and how ever indicated. Patients who continued pregnancy after the Doppler examination, Doppler was repeated at two weekly interval or as needed. Doppler study done within 7 days prior to termination of pregnancy was taken into consideration for the study. Mode of termination of pregnancy was decided depending on the clinical condition of patients and the indications. At the time of delivery neonatal details such as baby weight, APGAR score, meconium staining of liquor and neonatal intensive care unit admissions were noted.

4. Investigation: complete blood count, complete urine analysis, liver function tests, blood sugar, plus serum anticardiolipine and protein $\mathrm{C} \&$ protein $S$.
The complete history was taken through a sheet form that consists of: Personal history, $\mathrm{C} / \mathrm{O}$ and history of present illness, menstrual history, obstetric history, past history and family history.

Full clinical examination was done consists of: General examination, abdominal examination and auscultation of fetal heart sounds.

Ultrasound and Doppler studies were carried out and repeated every two Weekes or as indicated to determine: Composite ultrasound gestational age, estimated fetal weight and umbilical and middle cerebral Doppler indecies (3 indecies S/D \& RI \& PI).

\section{Technique of Ultrasound and Doppler} examination: Trans abdominal ultrasound, umbilical artery Doppler and middle cerebral artery Doppler.

\section{Statistical methods:}

Data were coded and entered using the statistical package SPSS version 25. Data was summarized using mean and standard deviation for quantitative variables and frequencies (number of cases) and relative frequencies (percentages) for categorical variables. Comparisons between groups were done using unpaired $\mathrm{t}$ test. For comparing categorical data, Chi square ( $\square 2$ ) test was performed. Exact test was used instead when the expected frequency is less than 5. P-values less than 0.05 were considered as statistically significant. 


\section{THE CORRELATION BETWEEN ANTI CARDIOLIPINE \& PROTEIN C... 99}

\section{RESULTS}

In this study the mean maternal age of pregnant women with IUGR babies $(\mathrm{n}=100)$, was in range of $18-38$ years. Higher incidence was noted in women in the 20-30 years age group $(n=88)$. This was followed by patients that constituted the $<20$ age group or $>30$ years age group. Primipara $(\mathrm{n}=58)$ constituted $58 \%$ and multipara $(n=42)$ constituted $42 \%$. In this study multiparous patients were marginally less than the primi group. (Table 1).

Table (1): Age and parity distribution of cases and control group

\begin{tabular}{|l|c|c|c|c|}
\hline & $\begin{array}{c}\text { Cases No. } \\
(\mathbf{n = 1 0 0})\end{array}$ & $\%$ & $\begin{array}{c}\text { Control No. } \\
(\mathbf{n = 3 0})\end{array}$ & $\%$ \\
\hline Age in years: \\
\hline 20 or less & 10 & $10 \%$ & 3 & $10 \%$ \\
\hline $20-25$ & 44 & $44 \%$ & 15 & $50 \%$ \\
\hline $26-30$ & 44 & $44 \%$ & 10 & $30 \%$ \\
\hline More than 30 & 2 & $2 \%$ & 3 & $10 \%$ \\
\hline Parity: & \multicolumn{5}{|l|}{} \\
\hline PG & 58 & $58 \%$ & 21 & $70 \%$ \\
\hline multipara & 42 & $42 \%$ & 9 & $30 \%$ \\
\hline
\end{tabular}

In our study $58(58 \%)$ of the IUGR cases found in Normotensives, 24 (24\%) of cases were found in mild hypertensives 12 were PG and 12 multipara and 11 $(11 \%)$ of cases were found in moderate hypertensives 4 of them were PG and 7 (7\%) of cases were found in sever hypertensives 4 of them were PG. (Table 2).

Table (2): Distribution of IUGR cases according to hypertensive disorder (PIH \& PET) (42 patient out of 100)

\begin{tabular}{|c|c|c|c|c|c|}
\hline $\begin{array}{c}\text { IUGR in hypertensive } \\
\text { disorder(PIH \& PET) }\end{array}$ & PG & G2 & G3 & $\begin{array}{c}\text { G4 or } \\
\text { more }\end{array}$ & Total \\
\hline Normotensive & 38 & 6 & 6 & 8 & 58 \\
\hline Mild & 12 & 1 & 3 & 8 & 24 \\
\hline Moderate & 4 & 1 & 1 & 5 & 11 \\
\hline (Symptoms) or Sever HB<6 & 4 & - & - & 3 & 7 \\
\hline Total & 58 & 8 & 10 & 24 & 100 \\
\hline
\end{tabular}

In our study almost $76 \%$ of IUGR babies delivered from mothers with normal blood sugar. (Table 3).

Table (3): Distribution of IUGR cases according to Diabetes mellitus (24 patient out of 100)

\begin{tabular}{|c|c|c|c|c|c|}
\hline IUGR with (Diabetes mellitus) & PG & G2 & G3 & G4 or more & Total \\
\hline Normotensive BL.sugar & 56 & 4 & 6 & 10 & 76 \\
\hline Mild Diabetes mellitus (Diet Control) & 1 & 1 & 4 & 8 & 14 \\
\hline $\begin{array}{c}\text { Moderate Diabetes mellitus (Insulin } \\
\text { Control) }\end{array}$ & 1 & 1 & 2 & 4 & 8 \\
\hline uncontroled Diabetes mellitus & - & - & - & 2 & 2 \\
\hline Total & 58 & 8 & 10 & 24 & 100 \\
\hline
\end{tabular}


In our study majority of IUGR babies $86 \%$ delivered from mothers with normal hemoglobin. (Table 4).

Table (4): Distribution of IUGR cases according to Anemia (14 patient out of 100)

\begin{tabular}{|c|c|c|c|c|c|}
\hline IUGR with (Anemia) & PG & G2 & G3 & $\begin{array}{c}\text { G4 or } \\
\text { more }\end{array}$ & Total \\
\hline Normotensive HB & 54 & 6 & 10 & 16 & 86 \\
\hline Mild Anemia & 3 & 1 & 2 & 2 & 8 \\
\hline Moderate Anemia & 1 & 1 & 1 & 3 & 6 \\
\hline Symptom (Sever Anemia) & - & - & - & - & - \\
\hline Total & 58 & 8 & 13 & 21 & 100 \\
\hline
\end{tabular}

In this study group of 100 pregnant mothers, the gestational age at the time of
Doppler examination started ranged between 28to 32 weeks. (Table 5).

Table (5): Distribution of gestational age at Doppler examination

\begin{tabular}{|c|c|c|c|c|}
\hline Gestational age & $\begin{array}{c}\text { Number } \\
(\mathbf{n = 1 0 0})\end{array}$ & $\boldsymbol{\%}$ & $\begin{array}{c}\text { Control } \\
(\mathbf{n = 3 0})\end{array}$ & $\boldsymbol{\%}$ \\
\hline $\mathbf{2 8 - 3 0}$ & 20 & $20 \%$ & 12 & $40 \%$ \\
\hline $\mathbf{3 0 - 3 2}$ & 80 & $80 \%$ & 18 & $60 \%$ \\
\hline Total & 100 & $100 \%$ & 30 & $100 \%$ \\
\hline
\end{tabular}

Majority i.e. eighty of the pregnant females examined were from 30-32 weeks of gestation. None of the females were examined before 28 weeks since Doppler parameters stabilize by 28 weeks of gestation. (Table 6).

Table (6): The main risk factor (Maternal Risk factor) at Doppler examination started in cases

\begin{tabular}{|l|c|c|}
\hline \multicolumn{1}{|c|}{ Main risk factor } & Number $(\mathbf{n = 1 0 0})$ & Percentage \\
\hline Hypertension with pregnancy & 42 & $42 \%$ \\
\hline Diabetes mellitus with pregnancy & 24 & $34 \%$ \\
\hline Anemia with pregnancy & 14 & $14 \%$ \\
\hline previous history of IUGR & 12 & $12 \%$ \\
\hline No obvious risk & 8 & $8 \%$ \\
\hline
\end{tabular}

In this study there is statistical significance with lower Middle cerebral artery indices in cases compared to control group. In this study there is statistical significance with high indices in U.A. indices in cases compared to control group. In this study there is statistical significance of positive Thrombophilia markers PRO.S.D., PRO.C.D., ACLA in cases compared to control group. (Table 7). 
THE CORRELATION BETWEEN ANTI CARDIOLIPINE \& PROTEIN C... ${ }^{101}$

Table (7): Middle cerebral artery, umbilical artery indices and Thrombophilia markers PRO.S.D., PRO.C.D., ACLA in cases and control group

\begin{tabular}{|c|c|c|c|c|c|c|}
\hline & \multicolumn{4}{|c|}{ Group } & \multirow{3}{*}{$P$ value } \\
\hline & & \multicolumn{2}{|c|}{ Cases } & \multicolumn{2}{|c|}{ Control } & \\
\hline & & Mean & $\begin{array}{l}\text { Standard } \\
\text { Deviation }\end{array}$ & Mean & $\begin{array}{l}\text { Standard } \\
\text { Deviation }\end{array}$ & \\
\hline \multirow{3}{*}{$\begin{array}{c}\text { Middle } \\
\text { cerebral } \\
\text { artery indices }\end{array}$} & $\begin{array}{c}\text { S/DR middle cerebral } \\
\text { artery }\end{array}$ & 4.03 & 1.59 & 7.91 & .89 & $<0.001$ \\
\hline & $\begin{array}{l}\text { RI middle cerebral } \\
\text { artery }\end{array}$ & .66 & .11 & .78 & .05 & $<0.001$ \\
\hline & $\begin{array}{c}\text { PI middle cerebral } \\
\text { artery }\end{array}$ & 1.27 & .26 & 2.33 & .38 & $<0.001$ \\
\hline \multirow{3}{*}{$\begin{array}{c}\text { Umbilical } \\
\text { artery indices }\end{array}$} & SDR umbilical artery & 4.83 & 1.10 & 2.68 & .49 & $<0.001$ \\
\hline & RI umbilical artery & .79 & .14 & .51 & .04 & $<0.001$ \\
\hline & PI umbilical artery & 1.30 & .26 & 1.22 & .07 & $<0.001$ \\
\hline & & Count & $\%$ & Count & $\%$ & \\
\hline \multirow{2}{*}{ PR.S.D. } & Positive & 24 & $24.0 \%$ & 1 & $3.3 \%$ & \multirow{2}{*}{0.012} \\
\hline & Negative & 76 & $76.0 \%$ & 29 & $96.7 \%$ & \\
\hline \multirow{2}{*}{ PR.C.D. } & Positive & 21 & $21.0 \%$ & 1 & $3.3 \%$ & \multirow{2}{*}{0.024} \\
\hline & Negative & 79 & $79.0 \%$ & 29 & $96.7 \%$ & \\
\hline \multirow{2}{*}{ ACLA } & Positive & 30 & $30.0 \%$ & 1 & $3.3 \%$ & \multirow{2}{*}{0.003} \\
\hline & Negative & 70 & $70.0 \%$ & 29 & $96.7 \%$ & \\
\hline
\end{tabular}

\section{DISCUSSION}

The present study included 130 pregnant women divided into 100 diagnosed with IUGR and 30 with normal pregnancy. As regards the hemodynamic parameters, the cases had a higher umbilical index and lower middle cerebral Doppler indices (S/D ratio, RI, PI) compare to the control group. This was in agreement with the study done by Lakhkar et al. (2013) who investigated fifty-eight singleton pregnancies beyond 30 weeks of gestation complicated by intrauterine growth restriction, they found that in IUGR first there was decreased diastolic flow in the umbilical artery and raises the S/D ratio, PI and RI of umbilical artery than in normal pregnancy. The results of our study also agrees with Fuchs et al.
(2010), who investigated 22 pregnant women between the 28th and 40th week of pregnancy with IUGR detected by ultrasound examination and 19 pregnant women between 28th and 41st week of pregnancy as a control group. They found that umbilical Doppler indices (S/D ratio, RI, PI) in the cases were significant higher than in controls group but lower than control in middle cerebral artery indices. Also agree with (Yoshimura et al., 2010) who investigated 100 normal fetuses and 105 intrauterine growth-retarded fetuses. In growth retarded fetuses, high umbilical artery Doppler indices (S/D ratio, RI, PI) and low middle cerebral artery Doppler indices (S/D ratio, RI, PI), the so called "brain sparing effect" was demonstrated. 
Similar study in the year 2000 by Kim et al. (2010) revealed that in umbilical artery, Doppler indices (S/D ratio, RI, PI) of IUGR fetuses were significantly higher than that of normal fetuses $(3.34 \pm 0.69 \mathrm{vs}$ $2.29 \pm 0.29 ; \quad \mathrm{p}<0.01, \quad 1.27 \pm 0.27 \mathrm{vs}$ $0.81 \pm 0.14 ; \quad \mathrm{p}<0.01, \quad 0.70 \pm 0.07 \mathrm{vs}$ $0.55 \pm 0.06 ; \mathrm{p}<0.01)$. In middle cerebral artery, Doppler indices (S/D ratio, RI, PI) of IUGR fetuses was significantly lower than that of normal fetuses $(0.72 \pm 0.09 \mathrm{vs}$ $0.82 \pm 0.07 ; \mathrm{p}<0.01)$. They concluded that umbilical blood flow was affected but middle cerebral blood flow was maintained in IUGR fetuses. So fetal blood flow redistribution in favor of the brain at development of IUGR may be present and detectable by Doppler ultrasonography using Cerebroplacental ratio (Kim et al., 2010).

The first step in the management of IUGR fetus is diagnosis. Doppler velocimetry is the most important means of diagnosing the IUGR fetus that is at risk for adverse perinatal morbidity and mortality. The Doppler velocimetry identifies normal and altered blood flow in the middle cerebral and umbilical arteries in response to placental resistance. Various workers found out that perinatal morbidity and mortality was significantly greater in IUGR, (Pathologically small babies) than babies with normal Doppler studies (physiologically small) (Nalini et al., 2015).

Our study agree with Nalini et al. (2015) in that, Doppler ultrasonography in severe IUGR fetuses revealed progressive reduction in pulsatality index and S/D ratio of middle cerebral artery consistent with brain sparing effect when used for prediction of adverse perinatal outcomes.

\begin{abstract}
Absent or reversal end diastolic flow of umbilical artery and that of abnormal middle cerebral artery have the sensitivity, specificity and positive predictive value in the range of $71 \%, 92 \%$ and $94 \%$ respectively.
\end{abstract}

Our study reveal Similar results regarding distribution of cases according to mode of delivery shows more no of Csections $(60 \%)$ were done in cases with abnormal Doppler waveforms when compared to the normal Doppler waveforms (10\%). This compares with the results published by Dhand et al. (2011), $84 \%$ of their cases with abnormal Doppler flows, were subjected to caesarean section where as $50 \%$ cases with normal Doppler flows underwent caesarean section. $4 \%$ of the cases needed termination of the pregnancy on account of severe oligohydromnios in fetuses with reversal of flow in umbilical artery whereas none of the cases with normal Doppler flow required termination of pregnancy.

Our study shows high prevalence of thrombophilia in women coming for antenatal care at AL-Azhar university Hospitals (alhussin), who had pregnancy complicated by IUGR fetuses showing thrombophilia was more prevalent in cases with IUGR pregnancy than in normal pregnancy, Maternal thrombophilia has recently been identified as a major cause of thromboembolism, placental thrombosis, and adverse pregnancy outcome, including severe preeclampsia, placental abruption, intrauterine growth restriction, recurrent pregnancy loss, and stillbirth (Blumenfeld et al., 2010).

The most common inherited disorders are deficiencies of antithrombin III, 
protein $\mathrm{C}$, and protein $\mathrm{S}$, activated protein $\mathrm{C}$ resistance due to factor $\mathrm{V}$ Leiden mutation, a function-enhancing mutation in the prothrombin gene (G20210A), and thermolabile mutation for methylenetetrahydrofolate reductase C677T (Younis et al., 2010).

Antiphospholipid syndrome is the most common cause of acquired thrombophilia; this is similar to what our study revealed. In addition it is associated with complications that span all trimesters of pregnancy, including recurrent miscarriage, severe preeclampsia, intrauterine growth restriction, and placental abruption (Kupferminc et al. 2010).

Our study discusses some thrombophilia factors (protein $\mathrm{C}$, protein $\mathrm{S}$ and ACL) and adverse pregnancy outcomes (IUGR) and if correlated with Doppler indices in umbilical and middle cerebral artery to assess available management options. As general review Protein $\mathrm{C}$ and Protein $\mathrm{S}$ deficiencies Protein $\mathrm{C}$ is a naturally occurring anticoagulant, which inactivates factor $\mathrm{Va}$ and VIIIa. This process is greatly enhanced in the presence of protein $S$, another natural anticoagulant, which exists in a free active form (40\%) and an inactive form bound to C4b-binding protein $(60 \%)$ (Girling and de Swiet, 2010).

Various study reveal, the relatively high prevalence of thrombophilic defects in the general population and the association with adverse maternal and fetal outcomes have prompted obstetricians to focus their interest to this area. Our study reveal high proportion of thrombophilia defect in IUGR cases than in control, this agreed with data from the European Prospective Cohort on thrombophilia study showed a modest increase in the risk of IUGR, stillbirth among women with protein $\mathrm{C}$ deficiency ( $1.2 \%$ vs $0.6 \%$, odds ratio $2.3,95 \%$ CI 0.6 to 8.3$)$ and protein $\mathrm{S}$ deficiency $(1.9 \%$ vs $0.6 \%$, odds ratio $3.3,95 \%$ CI 1.0 to 11.3 ), but no significant difference in the risk of miscarriage compared with controls (15.8\% vs $11.6 \%$, and $14.6 \%$ vs $11.6 \%$, respectively) (Preston et al., 2010).

Our study regarding association of APS with IUGR agree with other studies discussed other pregnancy Complications as Recurrent pregnancy loss which is one of the defining diagnostic criteria of antiphospholipid syndrome. It appears that most miscarriages in women with antiphospholipid syndrome occur when fetal heart activity has already been established. In contrast, miscarriages in women with negative antiphospholipid antibodies are usually an embryonic. Rai et al. (2010) examined the prevalence of antiphospholipid antibodies among 500 consecutive women with recurrent miscarriage. They found that $15 \%$ of them had persistently positive tests for antiphospholipid antibodies (62\% lupus anticoagulants only, $15 \% \quad \mathrm{IgG}$ anticardiolipin antibodies, 9\% immunoglobulin $\mathrm{M}$ anticardiolipin antibodies, 14\% lupus anticoagulants and anticardiolipin antibodies).

Although there is a general support for the association between mid-trimester pregnancy loss and antiphospholipid syndrome, the potential association with first-trimester pregnancy loss is controversial. MacLean et al. (2011), reported an increased prevalence of lupus 
Aiman M. Atitou et al.,

anticoagulant and anticardiolipin antibodies in women with a history of first trimester miscarriage.

However, other investigators reported a lack of an association between antiphospholipid antibodies and firsttrimester spontaneous miscarriages (Simpson et al., 2010). The exact mechanisms of placental mediated diseases are unknown. Placental infarction and/or thrombosis may play a critical role, although others were unable to confirm the high frequency of placental infarction. Current evidence suggests that antiphospholipid antibodies may interfere with various phospholipid-containing proteins, or complexes, including 2glycoprotein I, protein C, phospholipase $\mathrm{A} 2$, prothrombin, thrombomodulin, and annexin V (Lockshin, 2010).

Vora et al. (2012) found $75.6 \%$ of unexplained fetal loss had either an acquired, genetic or both markers of thrombophilia present.

Koeleman et al. (2010) reported FV leiden mutation was associated with protein $\mathrm{S}$ deficient probands $(38 \%)$, and activated protein c resistance among symptomatic protein-C probands.

This suggested high probability of presence of more than one thrombophilia in more severe cases. We found that there was increased severity of adverse pregnancy complicated by IUGR when there was presence of combined defect or more than 1 thrombophilia markers positive in this study. In our study, pregnant women with IUGR we concluded that there was association between thrombophilia and IUGR such that IUGR is increased in women with thrombophilia polymorphism. This finding was corresponded with some previous studies in which they found independent association between mutation of factor $\mathrm{V}$ leiden and prothrombin with the occurrence of fetal growth restriction (Yerspyck et al., 2010).

In our study we found that lower levels of free PS in maternal serum in the third trimester of pregnancy are correlated with IUGR. These data, in part, corroborate previous studies (Lefkowitz et al., 2010 and Paidas et al., 2011), suggesting that PS plays a role in the development of pregnancy. Some studies showed that a normal level of functional PS cannot be considered useful for diagnosis of PS deficiency, and must be integrated with the determination of free PS (Rodger et al., 2019).

Therefore, the present study emphasized the importance of the detection of FPS deficiency in pregnancy, and the importance of FPS deficiency in the pathogenesis of IUGR. In this study most of the prevalence was in protein $S$, and anti-cardiolipin that were associated with IUGR, but in the study done by Polzin and colleagues (2010), they reported that there is significant association between the presence of maternal anti-cardiolipin antibodies and fetal growth restriction. In contrast, in the study done by Claire et al. (2012), no association of thrombophilia polymorphism is found with IUGR. According to these studies. It is correctly stated by Alfirevic (2012), that there is wide heterogeneity in the prevalence of thrombophilia between different studies, but that is probably due to cases were selected from several different races worldwide. As treatment was found 
significantly effective in literature, screening of these markers should be done in patients with bad obstetric history.

\section{CONCLUSION}

The value and accuracy of the Doppler indices (S/D,RI\&PI) of the umbilical \& middle cerebral arteries and its correlation with some thrombophilia markers (anticardiolipin, protein $\mathrm{C} \&$ protein $\mathrm{S}$ ) in the IUGR, is a better index for predicting adverse outcomes in IUGR when compared with control group.

\section{REFERENCES}

1. Alfirevic Z, Roberts D and Martlew V. (2012): How strong is the association between maternal thrombophilia and adverse pregnancy outcome? A systematic review. Eur J Obstet Gynecol Reprod Biol., 101(1):6-14.

2. Bligh LN, Flatley CJ and Kumar S. (2019): Reduced growth velocity at term is associated with adverse neonatal outcomes in non-small for gestational age infants. Eur J Obstet Gynecol Reprod Biol., 240: 125-129.

3. Blumenfeld $Z$ (2010): Brenner B. Thrombophilia-associated pregnancy wastage. Fertil Steril., 72: 765- 74.

4. Claire IR, Georges-Etienne $R$ and Wagner $V$ (2012): Absence of association of thrombophilia polymorphism with intrauterine growth restriction. N Engl J Med., 347: 19-25.

5. Cunningham FG, Gant NF, Leveno KJ, Glistrap LC, Hauth JC and Wenstrom KD. (2010): Fetal growth disorder Williams Obstetrics 22th edition; The McGraw-Hill Companies, Pp. 743-760.

6. Rodger MA, Carrier M, Gervais $M$ and Rock G. (2012): Normal functional protein $\mathrm{S}$ activity does not exclude protein $\mathrm{S}$ deficiency. Pathophysiol Thromb Haemost., 33:202-5.

7. Dhand H, Kansal HK and Dave A. (2011): Middle cerebral artery Doppler indices better predictor for fetal outcome in IUGR. The Journal of Obstetrics and Gynecology of India, 61: 166-171.

8. Fuchs T, Zalewski J, Zimmer M, Florjański J, Pańczak K. (2010): Useful of cerebral placental ratio in pregnancies complicated by intrauterine growth retardation and it correlation with perinatal outcome. Ginekol Pol., 71(4):304-10.

9. Girling J and de Swiet M. (2010): Inherited thrombophilia and pregnancy. Curr Opin Obtet Gynecol., 10:135-44.

10. Gordijn SJ, Beune IM, Thilaganathan B, Papageorghiou A, Baschat AA, Baker PN, Silver RM, Wynia $K$ and Ganzevoort W. (2016): Consensus definition of fetal growth restriction: a Delphi procedure. Ultrasound Obstet Gynecol., 48: 333-339.

11. Hoffman E, Hedlund E, Perin T and Lyndrup J. (2012): Is thrombophilia a risk factor for placenta-mediated pregnancy complications? Arch Gynecol Obstet., 286: 585-589.

12. Karakantza M, Androutsopoulos G, Mongiou A, Sakellaropoulos G, Kourounis G and Decavalas G. (2012): Inheritance and perinatal consequences of Inherited thrombophilia in Greece. Int J Gynecol Obstet., 100: 124-129.

13. Kim YH. (2010): Umbilical venous blood gases, middle cerebral and renal arterial blood flow velocity waveforms in intrauterine growth restriction fetuses. International Journal of Research in Medical Sciences, 12(2): 145-154.

14. Kist WJ, Janssen NG, Kalk JJ, Hague WM, Dekker GA and de vries JI. (2012): Thrombophilias and adverse 
pregnancy outcome-A confounded problem. Thromb Haemost., 99(1): 7785.

15. Koeleman BPC, van Rumpt D, Hamulya'k K, Reitsma $P H$ and Bertina RM. (2010): Factor V Leiden: an additional risk factor for thrombosis in protein $\mathrm{S}$ deficient families? Thrombosis and Haemostasis, 74:580-3.

16. Kupferminc MJ, Eldor A, Steinman N, Many A, Bar-Am A and Jaffa A. (2010): Increased frequency of genetic thrombophilia in women with complications of pregnancy. $\mathrm{N}$ Engl $\mathrm{J}$ Med., 340(1):9-13.

17. Lakhkar BN, Rajagopal KV and Gourisankar PT. (2013): Doppler Prediction of Adverse Perinatal Outcome in PIH and IUGR. Ind J Radiol Imag., 16:1:109-116.

18. Lausman A, Kingdom J, Gagnon R, Basso $M$ and Bos H. (2013): Intrauterine growth restriction: screening, diagnosis, and management. Gynaecol Can., 35(8): 741-757.

19. Lefkowitz JB, Clarke SH and Barbour LA. (2010): Comparison of protein $S$ functional and antigenic assays in normal pregnancy. Am J Obstet Gynecol., 175: 657-60.

20. Lockshin MD. (2010): Pregnancy loss in the antiphospholipid syndrome. Thromb Haemostat., 82:641-8.

21. Maclean MA, Cumming GP, McCall F, Walker ID and Walker JJ. (2011): The prevalence of lupus anticoagulant and anticardiolipin antibodies in women with a history of first trimester miscarriages. $\mathrm{Br} \mathrm{J}$ Obstet Gynaecol., 101:103-6.

22. Miller SL, Huppi PS and Mallard C. (2014): The consequences of fetal growth restriction on brain structure and neurodevelopmental outcome. J Physiol., 594: 807-823.

23. Nalini YL, Jyothirmayi $K$ and Reddy CM. (2015): Fetal outcome in relation with Colour Doppler study of middle cerebral artery \& umblical artery in intrauterine growth restriction. International Journal of Research in Medical Sciences, 7: 1721-1725.

24. Nohuz E, Riviere $O$, Coste $K$ and Vendittelli F. (2020): Prenatal identification of small-for-gestational-age and risk of neonatal morbidity and stillbirth. Ultrasound Obstet Gynecol., 55: 621-628.

25. Paidas MJ, Ku DH and Lee MJ. (2011): Protein $Z$, protein $S$ levels are lower in patients with thrombophilia and subsequent pregnancy complications. J Thromb Haemost., 3:497-501.

26. Polzin WJ, Kopelman JN, Robinson SD, Read JA and Brady K (2010): The association of antiphospholipid antibodies with pregnancies complicated by fetal growth restriction. Obstetr Gynecol., 79(4): 637-8.

27. Preston FE, Rosendaal FR, Walker ID, Briet E, Berntorp $\mathrm{E}$ and Conard J. (2010): Increased fetal loss in women with heritable thrombophilia. Lancet, 348:913-6.

28. Rai R, Shlebak A, Cohen H, Backos M, Holmes Z, Marriott $K$ and Regan $L$. (2010): Factor $\mathrm{V}$ Leiden and acquired activated protein $\mathrm{C}$ resistance among 1000 women with recurrent miscarriage. Hum Reprod., 16: 961-5.

29. Sadler TW, Thomas $W$ and Lanmgan J. (2010): Langman's Medical Embryology. Wolters Kluwer, Lippincott Williams \& Wilkins, Philadelphia, Pennsylvania, USA, Pp. 1-385.

30. Salomon LJ, Alfirevic $Z$, Da Silva Costa F, Deter RL, Figueras F, Ghi T, 
Glanc P, Khalil A, Lee W, Napolitano R, Papageorghiou A, Sotiriadis A, Stirnemann J, Toi A and Yeo G. (2019): ISUOG Practice Guidelines: ultrasound assessment of fetal biometry and growth. Ultrasound Obstet Gynecol., 53: 715-723.

31. Simpson JL, Carson SA, Chesney C, Conley M, Metzger B and Aarons J. (2010): Lack of association between antiphospholipid antibodies and first trimester spontaneous abortion: prospective study of pregnancies detected within 21 days of conception. Ertil Steril., 69:814-20.

32. Vasak B, Koenen SV, Koster MP, Hukkelhoven CW, Franx A, Hanson MA and Visser GH. (2015): Human fetal growth is constrained below optimal for perinatal survival. Ultrasound Obstet Gynecol., 45: 162-167.

33. Vora S, Shetty S, Salvi V, Satoskar $P$ and Ghosh K. (2012): Thrombophilia and unexplained pregnancy loss in Indian patients. Natl Med J India, 21(3):116-9.
34. Yerspyck E, Borg JY, Le cam-Duchez $V$ and Goffinet F. (2010): Thrombophilia and Fetal growth restriction. Eur J Obstetr Gynecol Reprod Biol., 113: 36-40.

35. Yoshimura S, Masuzaki H, Gotoh $H$ and Ishimaru T. (2010): The relationship between blood flow redistribution in umbilical artery and middle cerebral artery and fetal growth in intrauterine growth retardation. Int $\mathbf{J}$ Gynaecol Obstet., 60(1):3-8.

36. Younis JS, Brenner B, Ohel G, Tal J, Lanir $N$ and Ben-Ami M. (2010): Activated protein $\mathrm{C}$ resistance and factor $\mathrm{V}$ Leiden mutation can be associated with first as well as second trimester recurrent pregnancy loss. Am J Reprod Immunol., 43:31-5.

37. Zelop CM, Javitt MC, Glanc P, Dubinsky $T$ and Harisinghani MG. (2013): ACR Appropriateness Criteria ${ }^{\circledR}$ growth disturbances - risk of intrauterine growth restriction. Ultrasound Q., 29(3): 147-151. 
در اسة مؤشر ات سريان الدم فى كل من الثريان المخى الثى الثي

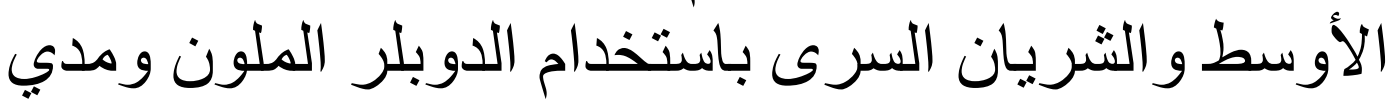

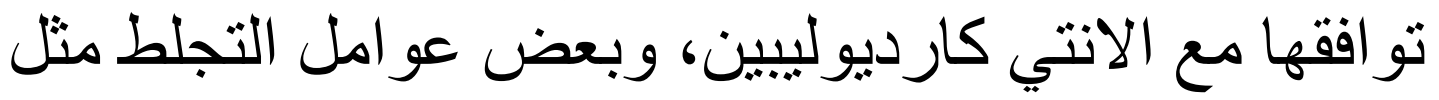
بروتين C وبروتين S في حالات نقص النمو في الجنين داخل الرحم

أيمن محمد عطيتو أحمد, يحي عبدالسلام وفا, فها عبدالعال محمد, صلاح أحمد البلتاجي*

قسمي النساء و التوليد, و الباثولوجيا الأكلينيكية*، كلية طب, جامعة الأزهر

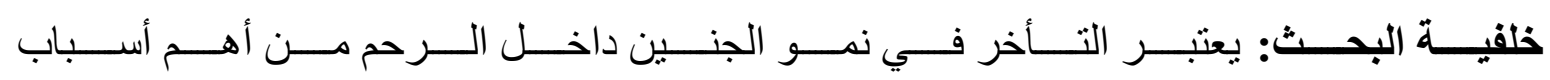

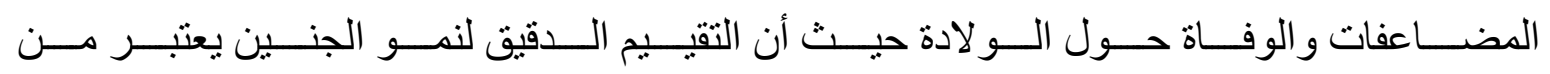

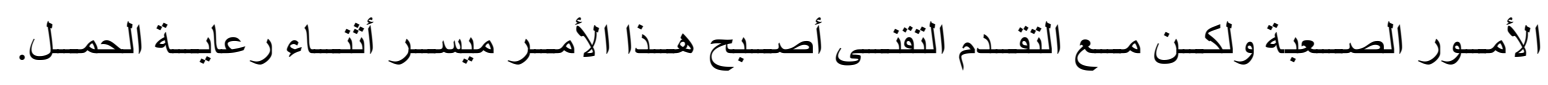

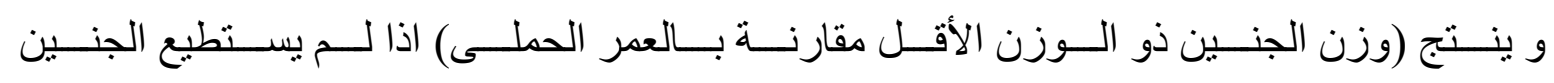

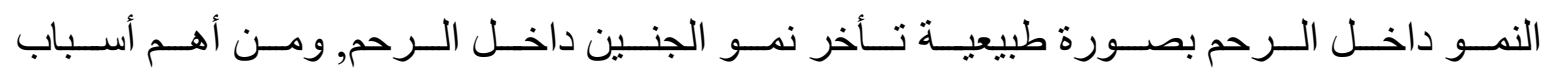

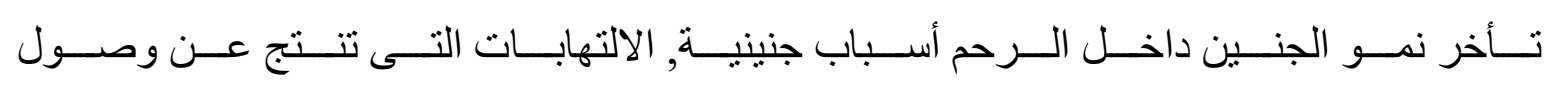

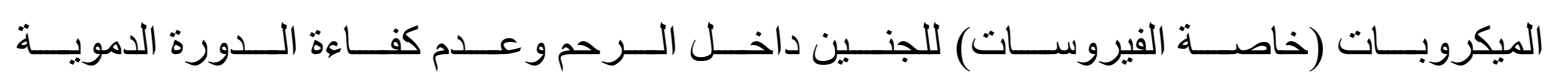
المشيمية الرحمية للارجة تؤثر على صحة الجنين ونموه.

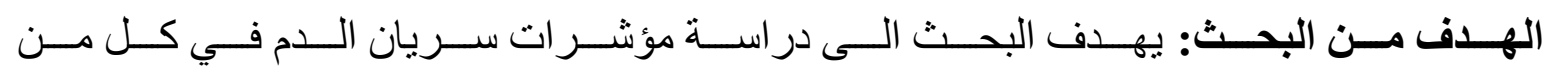

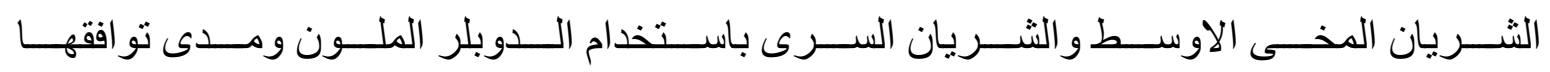

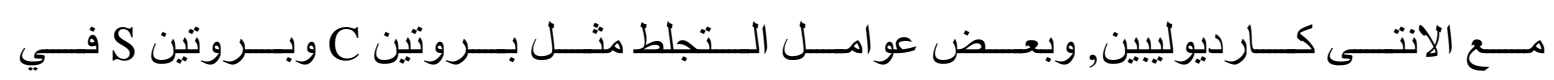

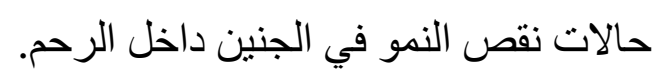

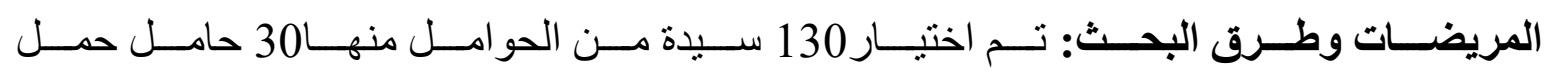

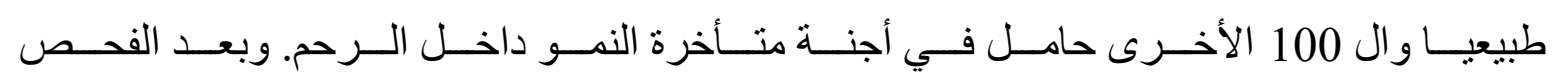

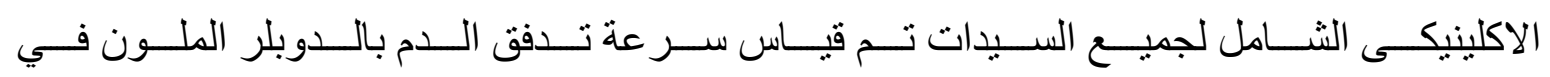

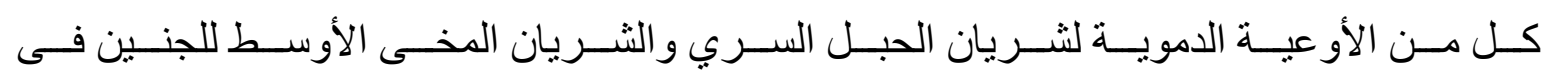

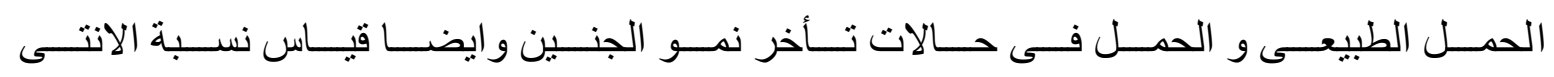


THE CORRELATION BETWEEN ANTI CARDIOLIPINE \& PROTEIN C... 109

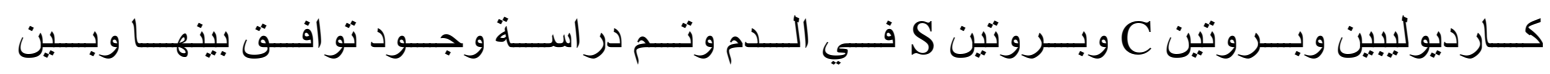
نتائج الوبلر من عدمه.

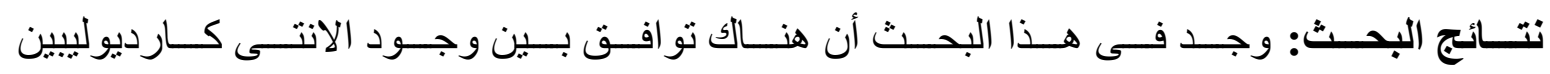

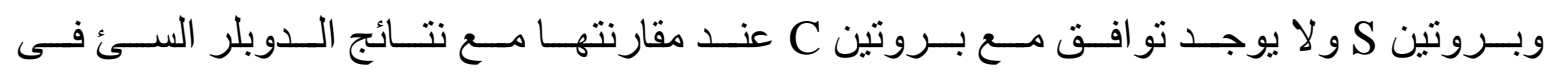
حالات تأخر نمو الجنين.

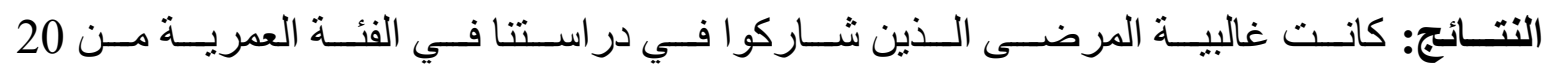

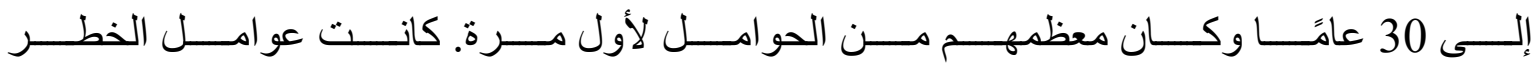

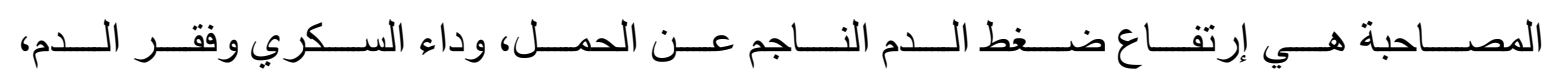

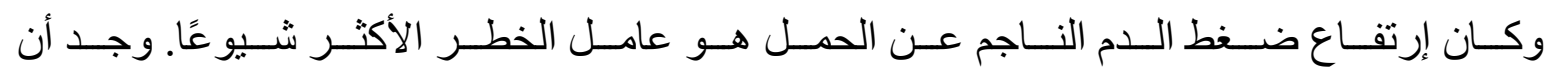

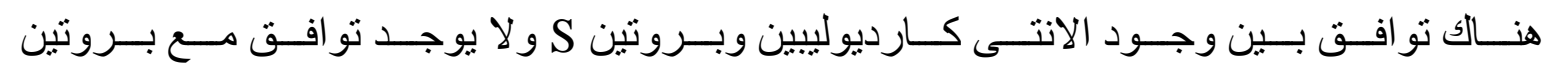

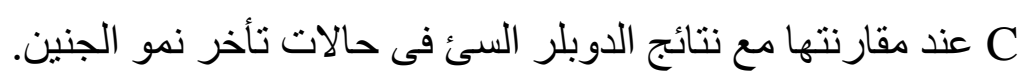

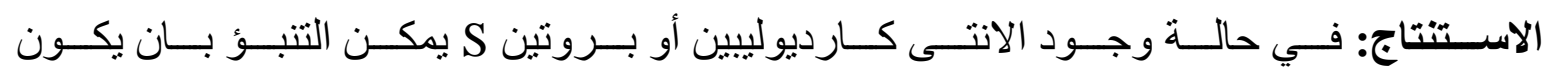
هناك دوبلر سئ في حالات نقص نمو الجنين داخل الرحم. 